\title{
Total Phenolic Content, Antioxidant and Antibacterial Activities of Sargassum polycystum of Ethanol Extract from Waters of Kabung Island
}

\author{
(Total Fenol, Aktivitas Antioksidan dan Antibakteri dari Ekstrak Etanol Sargassum \\ polycystum asal Perairan Pulau Kabung)
}

\author{
Ikha Safitri, Warsidah*), Mega Sari J. Sofiana, Arie A. Kushadiwijayanto, T. Novi Sumarni \\ Jurusan Ilmu Kelautan, Fakultas Matematika dan Ilmu Pengetabuan Alam, Universitas Tanjungpura \\ Jl. Prof. Dr. Hadari Nawawi Pontianak.
}

\section{ABSTRACT}

Sargassum policystum is one of the genus Sargassum from the brown macroalgae group which has an abundance of chemical constituents of fucoidan, fucoxanthin, phenolic acids and alginate which have important biological activities, such as antioxidants and antibacterials. This species thrives in the waters of Kabung Island, Bengkayang, West Kalimantan and has not been exploited so that it tends to act as a marine weed. This study aimed to determine the total phenolic content of the ethanolic extract of $S$. policystum and its antioxidant and antibacterial activity. Determination of the total content of phenolic compounds using the Folin Ciocalteu method, antioxidant testing using the DPPH method (2,2-diphenyl-1-picrylhydrazyl) and the indicator of sample color change with the addition of these radicals was measured by UV-Vis spectrophotometer. Antibacterial testing was carried out by the test sample diffusion method and the inhibition of the growth of the test bacteria Staphylococcus aureus and Escherichia coli as test bacteria was indicated by the formation of a clear area around the sample wells. The results showed that the phenol content of the ethanolic extract of $S$. policystum was $79.8 \mathrm{mg} / \mathrm{g}$ extract, its antioxidant activity (IC50) was $98.903 \mathrm{ppm}$, classified as a strong antioxidant, while the comparison antioxidant, Vitamin C, had an IC50 of $6.26 \mathrm{ppm}$. The inhibitory ability of the ethanol extract against the test bacteria used was indicated by the formation of the largest inhibition diameter on S. aureus of $12.4 \mathrm{~mm}$ and E. coli of $12.0 \mathrm{~mm}$.

Sargassum policystum adalah salah satu genus Sargassum dari golongan makroalga coklat yang memiliki kelimpahan kandungan kimia fukoidan, fukosantin, asam-asam fenolik dan alginat yang memiliki aktivitas biologik yang penting, seperti antioksidan dan antimikroba. Spesies ini tumbuh subur di perairan Pulau Kabung, Bengkayang, Kalimantan Barat dan belum dimanfaatkan sehingga cenderung bersifat sebagai gulma perairan laut. Penelitian ini bertujuan untuk menentukan kandungan total senyawa fenol dari ekstrak etanol S. policystum serta aktivitas antioksidan dan antibakterinya. Penentuan kandungan total senyawa fenol dengan metode Folin Ciocalteu, pengujian antioksidan menggunakan metode DPPH (2,2-diphenyl-1- picrylhydrazyl) dan indikator perubahan warna sampel dengan penambahan radikal tersebut diukur dengan spektrofotometer UV-Vis. Pengujian antibakteri dilakukan dengan metode difusi dan penghambatan pertumbuhan bakteri uji Staphylococcus aureus dan Escherichia coli sebagai bakteri uji ditunjukkan dengan terbentuknya zona bening di sekeliling sumuran sampel. Hasil penelitian menunjukkan kandungan fenol dari ekstrak etanol S. policystum adalah sebesar 12,85 mg/g ekstrak, aktivitas antioksidannya (IC50) sebesar 98,903 ppm, tergolong sebagai antioksidan kuat, sedangkan antioksidan pembanding yaitu vitamin C memiliki IC50 sebesar 6,26 ppm. Kemampuan penghambatan ekstrak etanol tersebut terhadap bakteri uji yang digunakan ditunjukkan dengan terbentuknya diameter hambatan yang paling besar pada bakteri S. aureus sebesar 12,4 mm dan E. coli sebesar 12,0 $\mathrm{mm}$.

Keywords: antioxidant, antimicrobial, DPPH, Sargassum policysticum.

E-mail: warsidah@fmipa.untan.ac.id 


\section{PENDAHULUAN}

Beberapa senyawa seperti polifenol dan pigmen telah dilaporkan sebagai senyawa yang potensial dikembangkan dalam dunia kesehatan. Senyawa pigmen fukosantin, karotenoid dan astaxantin serta senyawa polifenol seperti fenolik, flavonoid dan tanin banyak terkandung dalam rumput laut yang telah banyak dilaporkan memiliki aktivitas antioksidan dengan berbagai macam metode seperti penangkapan radikal bebas dan penghambatan reaksi peroksidasi lipid [1], [2] dan [3].

Radikal bebas dengan reaktivitas tinggi telah menjadi pemicu penyakit degeneratif seperti kardiovaskular, kanker dan peradangan. Meningkatnya jumlah radikal bebas akan mengakibatkan terjadinya stres oksidatif dalam sel [4]. Senyawa antioksidan adalah senyawa yang mampu menghambat proses oksidasi dan menunjang sistem pertahanan endogen dalam meminimalisir kerusakan oksidatif [5].

Antioksidan alami merupakan metabolit sekunder yang dapat dihasilkan oleh tumbuhan. Aktivitas biologik dari antioksidan alami yang berasal dari tumbuhan umumnya disebabkan oleh adanya kandungan senyawa fenol [6] dan [7]. Aktivitas penghambatan proses oksidasi senyawa fenol dalam tumbuhan berdasarkan pada kemampuannya mendonorkan elektron, mereduksi atau mengkhelat ion logam [8] dan [9].

Rumput laut atau dikenal dengan makroalga adalah salah satu tumbuhan laut yang dapat tumbuh alamiah atau dibudidayakan di lingkungan perairan laut, memiliki potensi antioksidan. Makroalga, secara taksonomi diklasifikasikan menjadi 3 kelompok besar yaitu makroalga hijau (Chlorophyta), makroalga coklat (Phaeophyta) dan makroalga merah (Rhodophyta). Makroalga coklat merupakan tumbuhan multiseluler dengan 1.800 keanekaragaman spesies, memiliki karakteristik warna hijau zaitun sampai coklat gelap, antara lain seperti genus Padina, Sargassum dan Laminaria. Genus Sargassum dengan keanekaragaman sekitar 400 spesies, di antaranya adalah S. policystum tersebar dengan suburnya di seluruh perairan Indonesia. Spesies ini, lebih dikenal sebagai gulma perairan, dalam masa tertentu dari pertumbuhannya akan lepas dari habitatnya dan terseret ombak ke tepi pantai. Spesies $S$. policystum adalah salah satu spesies makroalga coklat yang tumbuh subur di perairan Pulau
Kabung, Bengkayang, Kalimantan Barat dan belum termanfaatkan.

Makroalga coklat memiliki kelimpahan kandungan fukosantin, fukoidan, florotanin, terpenoid dan asamasam fenolik yang memiliki aktivitas biologik penting [10] dan [11]. Asam fenolat sebagai senyawa turunan fenolik mengandung sekurangnya satu gugus fungsional asam karboksilat, yang terbagi atas 2 golongan berdasarkan jalur biosintetisnya yaitu asam hidroksibenzoat dan asam hidroksisinamat. Asam hidroksibenzoat seperti asam galat merupakan derivat dari asam benzoat sedangkan asam hidroksisinamat seperti asam kafeat dan asam kumarat merupakan senyawa turunan dari sinamat [12]. Menurut Farvin dan Jacobsen [13], asam-asam fenolat antara lain seperti asam galat, asam protokatekuat dan hidroksibenzoat yang dikandung dalam hampir semua jenis makroalga sehingga memiliki kemampuan meredam radikal bebas dari DPPH dan mereduksi senyawa besi (III) klorida. Dengan demikian, setiap makroalga memiliki potensi yang kuat sebagai sumber senyawa fenol dan senyawa aktif lain yang memiliki kemampuan antioksidan. S. policystum juga mengandung makronutrien seperti protein, karbohidrat dan lemak serta mineral essensial seperti $\mathrm{Mg}, \mathrm{Na}, \mathrm{Fe}$ dan iodin. Uraian komponen nutrisi yang dikandung makroalga menunjukkan bahwa komoditas ini sebagai sumber nutrisi penting, sayangnya belum begitu populer di kalangan masyarakat.

Selain aktivitas antioksidan, Sargassum sp. memiliki potensi antimikroba, yaitu produk metabolisme sekunder yang dalam jumlah tertentu dapat merusak atau menghambat pertumbuhan mikroorganisme. Penelitian Sidawuruk dkk [14] menunjukkan kemampuan antimikroba dari ekstrak metanol $S$. plagyophyllum dalam menghambat pertumbuhan bakteri Listeria monocytogenes (kelompok gram positif) dan Pseudomonas aeruginosa (kelompok gram negatif).

Dalam penelitian ini akan dilakukan penentuan kandungan total fenol, pengujian aktivitas antioksidan dengan metode DPPH dan pengujian antibakteri menggunakan bakteri uji $S$. aureus dan E. coli dengan metode difusi sumuran dari ekstrak etanol S. policystum.

\section{METODE PENELITIAN}

\section{Ekstraksi $S$. policystum}

Sampel S. policystum diambil dari perairan Pulau Kabung. Sampel dibersihkan dari sampah dan rumput 
laut lainnya, kemudian dikeringanginkan selama 5 hari pada suhu kamar. Sampel yang telah kering selanjutnya dihaluskan dengan blender dan diayak dengan pengayak mesh 60. S. policysticum serbuk diambil sebanyak $500 \mathrm{~g}$ dan diekstraksi secara maserasi pelarut etanol (rasio 1:3), direndam selama 3 x 24 jam dalam ruangan gelap. Ekstrak hasil penyarian disaring untuk memisahkan ampas dan maserat. Maserat dipekatkan dengan rotary vacuum evaporator pada suhu $40{ }^{\circ} \mathrm{C}$ hingga diperoleh ekstrak kental.

\section{Penentuan Kandungan Total Fenol}

Penentuan kandungan total fenolik menggunakan metode Folin-Ciocalteau seperti yang dilakukan oleh Mega SJ Sofiana [15]. Sebanyak $5 \mathrm{mg}$ serbuk S. policystum dilarutkan dalam $2 \mathrm{~mL} 96 \%$ etanol, kemudian ditambahkan $5 \mathrm{~mL}$ air suling dan 0,5 mL reagent Folin-Ciocalteu 50\%, selanjutnya diinkubasi selama 5 menit dan ditambahkan $1 \mathrm{~mL} \mathrm{Na} \mathrm{CO}_{3} 5 \%$. Larutan dihomogenkan, diinkubasi dalam ruang gelap selama sejam, selanjutnya diukur dengan spektrofotometer pada panjang gelombang $725 \mathrm{~nm}$ dan replikasi tiga kali. Asam galat digunakan sebagai standar dibuat larutan berseri konsentrasi 0, 5, 10, 15 dan 20 ppm. Kurva kalibrasi dari larutan baku asam galat selanjutnya digunakan untuk menentukan kadar senyawa fenolik yang terkandung dalam ekstrak etanol S. policystum sampel menggunakan persamaan regresi dengan menyatakan satuan $\mathrm{mg}$ setara dengan asam galat per gram ekstrak (mg GAE / g ekstrak) mengikuti rumus:

$$
\begin{aligned}
& \mathrm{C}=\mathrm{C} 1 \times(\mathrm{V} / \mathrm{M}) \ldots \ldots \ldots \ldots \ldots \ldots \ldots \ldots \ldots \ldots \ldots \ldots \\
& \text { Di mana }: \\
& \mathrm{C}=\text { kandungan total fenol }(\mathrm{mg} \text { GAE } / \mathrm{g} \text { ekstrak), } \\
& \mathrm{C} 1=\text { konsentrasi asam galat }(\mathrm{mg} / \mathrm{L}) \\
& \mathrm{V}=\operatorname{volume}(\mathrm{L}) \\
& \mathrm{M}=\text { bobot ekstrak }(\mathrm{mg})
\end{aligned}
$$

\section{Pengujian Aktivitas Antioksidan}

Uji aktivitas penangkapan radikal bebas DPPH (2,2-diphenyl-1-picrylhidracyl) dilakukan seperti metode yang dilakukan Mega SJ Sofiana [16]. Dibuat larutan DPPH 0,1 $\mathrm{mM}$ DPPH reagen dilakukan dengan melarutkan 0,002 g DPPH dalam $50 \mathrm{ml}$ etanol 96\%. Dibuat larutan ekstrak etanol S. policystum konsentrasi 50, 100, 150, 200 dan 250 ppm, dan larutan antioksidan pembanding vitamin $C$ dengan konsentrasi 2, 4, 6, 8 dan $10 \mathrm{ppm}$. Diambil $1 \mathrm{~mL}$ dari masing-masing konsentrasi larutan sampel dan larutan pembanding untuk ditambahkan dengan $2 \mathrm{~mL}$ larutan stok DPPH 0,1 mM, dilakukan dalam suhu kamar, tanpa cahaya kemudian dibiarkan selama 30 menit sebelum dilakukan pengukuran absorbansi pada $\lambda_{\text {maks }}$ $516 \mathrm{~nm}$.

Persentase penghambatan radikal bebas dapat dihitung menggunakan persamaan berikut:

$$
\begin{gathered}
\mathrm{Ab}-\mathrm{Aa} \\
\text { Aktivitas inhibisi }(\%)=-\frac{\mathrm{Aa}}{\mathrm{Aa}} \mathrm{x} 100 \% \\
\text { Dimana } \mathrm{Ab}=\text { absorbansi blanko } \\
\mathrm{As}=\text { absorbansi sampe }
\end{gathered}
$$

\section{Pengujian Antibakteri}

Pengujian aktivitas antibakteri dari ekstrak etanol $S$. policystum dilakukan dengan metode difusi sumuran seperti yang dilakukan oleh Warsidah [17]. Bakteri uji yang digunakan adalah bakteri uji Staphylococcus aureus (Gram +) dan Escherichia coli (Gram -). Dari kultur bakteri uji dibuat suspensi, sebanyak $100 \mu \mathrm{L}$ dituang ke dalam cawan petri, kemudian ditambahkan media Nutrien Agar (NA) sebanyak $20 \mathrm{~mL}$, dihomogenkan dan dibiarkan sampai media memadat, kemudian dibuat sumuran berdiameter $5 \mathrm{~mm}$. Ekstrak etanol S. policystum dibuat dengan konsentrasi 5, 10, 15 dan $20 \%$, secara aseptik sebanyak $100 \mu \mathrm{L}$ dituang ke dalam sumuran, diinkubasi selama \pm 48 jam pada suhu $37^{\circ} \mathrm{C}$.

Aktivitas antibakteri ditandai dengan terbentuknya zona bening di sekitar sumuran, sebagai efek dari terhambatnya pertumbuhan bakteri uji.

Diameter zona hambat ditentukan sebagai berikut: Zona hambat $=$ diameter zona hambat terbentuk $(\mathrm{mm})$ - diameter sumur (mm).

\section{HASIL DAN PEMBAHASAN}

Senyawa fenolik adalah salah satu hasil metabolit sekunder, tidak memiliki peran langsung terhadap berlangsungnya proses fotosintetis dan reproduksi. Metabolit sekunder ini dihasilkan oleh organisme dalam kondisi cekaman seperti kekurangan nutrisi, suhu, pH dan salinitas. Herero [18] melaporkan ditemukannya senyawa fenol hidroksinamit dan asam benzoat serta turunannya pada makroalga hijau, kemudian oleh Suleria [19] melaporkan bahwa kandungan fenolik makroalga coklat lebih tinggi dari yang dikandung oleh makroalga merah dan hijau. 
Selain itu, makroalga coklat juga mengandung senyawa florotanin seperti floroglusinol, ekol, dan diekol yang memiliki aktivitas antibakteri. Beberapa penelitian melaporkan tentang kandungan total fenol makroalga Sargassum antara lain adalah Sargassum horneri sebesar 0,40 $\pm 0,01 \mathrm{mg}$ asam galat/g ekstrak kering, Sargassum thunbergii sebesar 0,29 $\pm 0,01 \mathrm{mg}$ asam galat/g ekstrak kering [20], dan Sargassum marginatum sebesar $11 \mathrm{mg}$ asam galat/g ekstrak [21].

Dalam penelitian ini dilakukan ekstraksi menggunakan pelarut etanol berdasarkan efektivitas penyarian senyawa fenol dalam bahan alam. Menurut Mc Donald dkk [22], bahwa besarnya afinitas suatu senyawa organik yang diekstraksi dari tanaman akan tergantung pada polaritas pelarutnya. Senyawa fenolik bersifat polar, akan lebih efektif diekstraksi menggunakan pelarut polar seperti etanol.

Folin-Ciocalteau adalah pereaksi yang dapat mengidentifikasi keberadaan senyawa fenol dalam suatu matrik sampel [23]. Folin-Ciocalteau terdiri atas asam fosfomolibdat-fosfotungsat ketika bereaksi dengan senyawa fenol akan tereduksi menjadi molibdenum tungsat yaitu kompleks yang berwarna biru, di mana intensitasnya warna yang terjadi akan sebanding besarnya konsentrasi ion fenolat dalam sampel. Dari hasil perhitungan kandungan total fenol yang dikandung ekstrak etanol $S$. policystum asal perairan Pulau Kabung adalah sebesar 12,85 mg asam galat/g ekstrak kering. Pada makroalga coklat lainnya yaitu Padina pavonica dari perairan yang sama dilaporkan kandungan total fenol ekstrak etanolnya adalah sebesar 20,34 mg asam galat/gram ekstrak [15]. Angka total fenol dalam ekstrak etanol $S$. policystum lebih tinggi daripada total fenol yang dikandung oleh beberapa spesies Sargassum di perairan lain. Jenis makroalga, iklim dan lokasi geografis pengambilannya akan sangat menentukan tinggi rendah produktivitas dan kualitas dari kandungan total fenolik di dalamnya [24].

Penentuan antioksidan ekstrak etanol S. policystum dilakukan dengan metode DPPH. Metode DPPH digunakan lebih luas dalam penentuan potensi antioksidan di mana dalam reaksi antara senyawa aktif dengan DPPH sebagai radikal bebas, maka radikal bebas DPPH akan tertangkap oleh senyawa aktif antioksidan sehingga terjadi elektron yang berpasangan yang ditandai dengan terjadinya pemucatan warna ungu dari DPPH [25]. Semakin besar kemampuannya untuk menangkap radikal bebas DPPH, maka intensitas warnanya makin pudar. Senyawa fenol dan senyawa-senyawa aktif lainnya yang bersifat antioksidan dalam ekstrak etanol $S$. policystum, akan menangkap radikal bebas DPPH. Senyawa fenol memiliki gugus hidroksi dan menjadi donor hydrogen, sehingga terstabilkan oleh resonansi dari struktur fenolik. Kandungan total fenol setara dengan aktivitas antioksidan. Aktivitas antioksidan dapat ditunjukkan dengan persen penghambatan atau nilai $\mathrm{IC}_{50}$, dimana $\mathrm{IC}_{50}$ rendah menunjukkan aktivitas antioksidan yang tinggi.

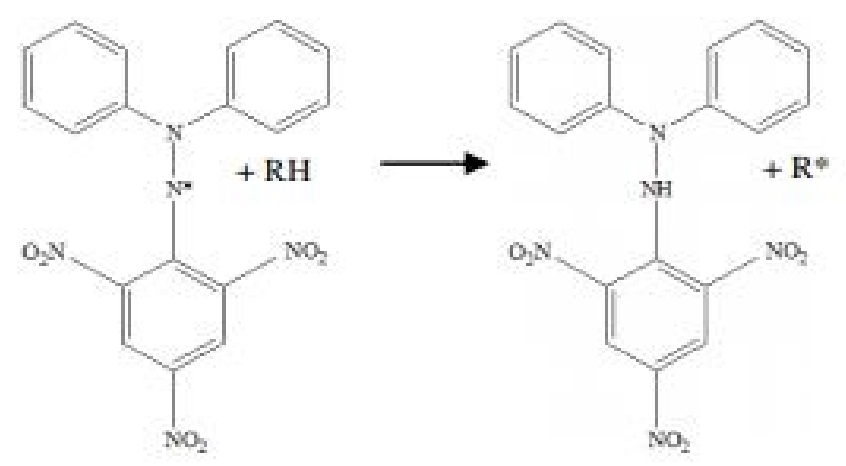

Gambar 1. Reaksi reduksi 1,1-diphenil-2- pikrilhidrazil (DPPH) dari antioksidan [28] 


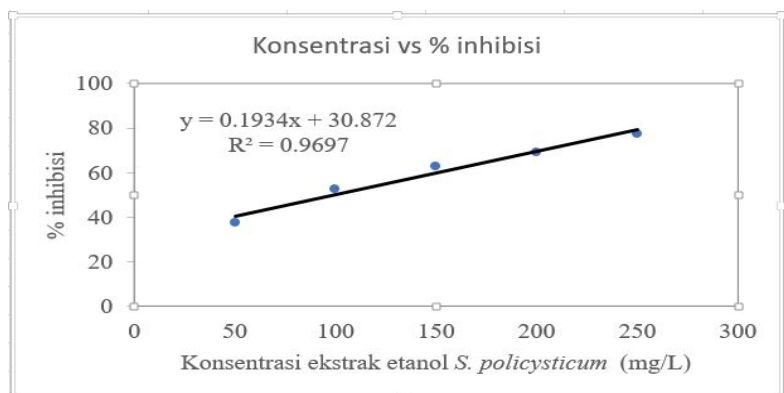

a)

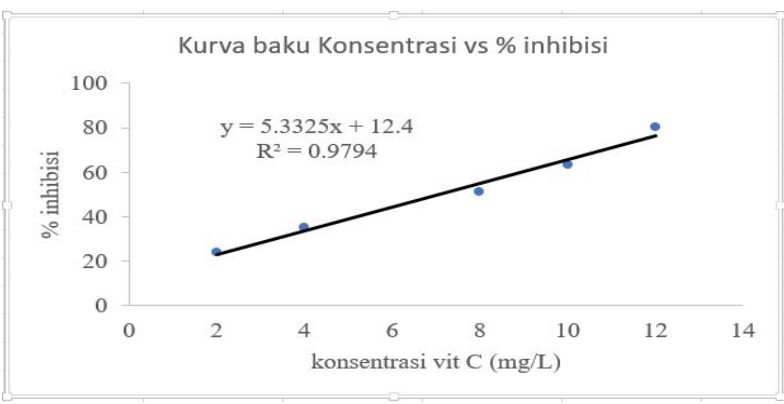

b)

Gambar 2. Kurva baku konsentrasi vs \% inhibisi a) Ekstrak etanol S. policystum b) Vitamin C

Kurva baku antara konsentrasi dan persen (\%) penghambatan radikal bebas pada gambar 2 menunjukkan semakin tinggi konsentrasi yang digunakan, persen penghambatan (inhibisi) juga semakin tinggi. Dengan memplotkan hasil pengukuran sampel pada kurva baku tersebut, diperoleh nilai $\mathrm{IC}_{50}$ sebagai ukuran aktivitas antioksidan. $\mathrm{IC}_{50}$ menunjukkan konsentrasi dari ekstrak yang digunakan dalam menangkap $50 \%$ radikal bebas DPPH dalam reaksi tersebut sehingga menghambat terjadinya oksidasi. Nilai $\mathrm{IC}_{50}$ yang terukur adalah 98,903 ppm tergolong sebagai antioksidan kuat. Aktivitas antioksidan dikategorikan menjadi tiga, yaitu antioksidan sangat kuat $(<50 \mathrm{ppm})$, kuat (50-100 ppm), lemah (100-150 ppm) [26]. Aktivitas antioksidan ekstrak ini lebih lemah daripada aktivitas antioksidan ( $\left.\mathrm{IC}_{50}\right)$ yang dilaporkan oleh Hwang dkk [27] dan Boonchum dkk. [28] pada $S$. bemiphyllum dan S. binderi yaitu sebesar 1,58 ppm dan 45,047 ppm. Ekstrak Sargassum sp yang mengandung polifenol tinggi memiliki nilai $\mathrm{IC}_{50}$ paling rendah [29].

Kandungan polifenol akan berbanding lurus dengan aktivitas antioksidannya. Berdasarkan penelitian Cahyaningrum dkk [30] tingginya kandungan polifenol dalam ekstrak $S$. policystum asal pantai Poktunggal Kabupaten Gunungkidul DIY yang diekstraksi dengan metode yang berbeda dari penelitian ini menghasilkan polifenol sebesar 1,18 mg asam galat/mg ekstrak, dengan aktivitas antioksidan $\mathrm{IC}_{50}$ 1,27 ppm. Polifenol adalah salah satu senyawa yang dihasilkan makroalga, digunakan sebagai perlindungan diri dari sinar matahari [31].

Aktivitas antibakteri dari ekstrak etanol $S$. polycystum dilakukan dengan metode sumuran menggunakan bakteri uji $S$. aureus dan E. coli dan antibiotik tetrasiklin sebagai pembanding. Aktivitas antibakteri ditunjukkan dengan pembentukan zona hambat sekitar sumuran.

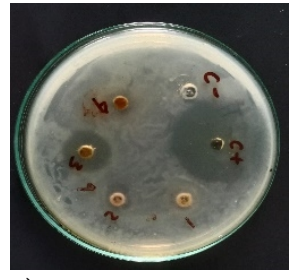

a)

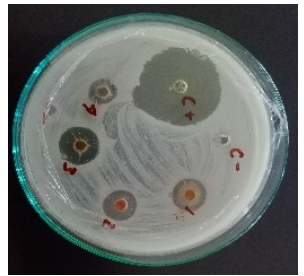

b)
Gambar 3. Zona hambat dengan bakteri uji a) Staphylococcus aureus dan b) Escherichia coli

Berdasarkan hasil uji aktivitas antibakteri dengan mengukur zona hambat pada kedua medium dengan bakteri uji $S$. aureus dan E.coli menunjukkan bahwa ekstrak etanol $S$. policystum memiliki aktivitas penghambatan terhadap pertumbuhan kedua bakteri uji tersebut (Gambar 3a dan 3b).

Tabel 1. Zona hambat ekstrak etanol S. policystum pada bakteri uji

\begin{tabular}{cccccc}
\hline \multirow{2}{*}{ Bakteri Uji } & \multicolumn{4}{c}{ Rerata zona hambat (diameter $=\mathrm{mm})$} \\
\cline { 2 - 5 } & \multicolumn{3}{c}{ Ekstrak etanol $S$. policystum } & Tetrasiklin \\
\cline { 2 - 5 } & $5 \%$ & $10 \%$ & $15 \%$ & $20 \%$ & \\
\hline $\begin{array}{c}\text { Staphylococcus } \\
\text { aureus }\end{array}$ & 6,6 & 7,6 & 12,0 & 6,2 & 21,4 \\
Escherichia coli & 5,6 & 7,2 & 12,4 & 5,2 & 20,4 \\
\hline
\end{tabular}

Pada kedua bakteri uji, zona hambatan terbesar dihasilkan pada konsentrasi ekstrak etanol $S$. policystum sebesar $15 \%$ yaitu pada $S$. aureus dan E. coli masingmasing sebesar 12,0 $\mathrm{mm}$ dan 12,4 $\mathrm{mm}$. Zona hambat ekstrak etanol S. policystum pada konsentrasi 15\% dengan diameter terbesar menunjukkan aktivitas antibakteri berkategori kuat dimana masuk dalam rentang daerah hambatan 10-20 $\mathrm{mm}$ sedangkan ekstrak etanol S. policystum konsentrasi 5, 10 dan 20\% 
termasuk dalam kategori sedang dengan rentang diameter zona hambatan sebesar 5-10 $\mathrm{mm}$ [32].

Secara umum, dari Gambar 3 menunjukkan diameter zona hambat dari ekstrak etanol S. policystum terhadap $S$. aureus lebih besar daripada $E$ coli. $S$. aureus adalah bakteri gram positif dan E. coli gram negatif [33]. Perbedaan aktivitas antibakteri ini dapat disebabkan karena komposisi dinding sel yang berbeda dari kedua bakteri uji. Struktur dinding sel bakteri gram negatif memiliki lapisan berlapis dan lebih komoleks dibandingkan bakteri gram positif sederhana [34]. Dinding sel bakteri gram negatif terdiri dari lipopolisakarida, protein dan fosfolipid [35]. Oleh karena itu, senyawa antibakteri akan lebih sulit untuk menembus dinding sel bakteri gram negatif [34]. Zona hambat yang terbentuk tidak hanya dipengaruhi oleh senyawa bioaktif yang terkandung didalamnya, tetapi juga faktor lain seperti kecepatan difusi, ukuran molekul, jumlah organisme yang diinokulasi, konsentrasi dan stabilitas senyawa antibakteri [36].

\section{KESIMPULAN}

Dari hasil penelitian ini dapat disimpulkan bahwa kandungan total senyawa fenol dengan metode folin Folin Ciocalteu dari ekstrak etanol S. policysticum sebesar $12.85 \mathrm{mg} / \mathrm{g}$ ekstrak. Aktivitas antioksidan (IC50) dari ekstrak etanol S. policysticum sebesar 98,903 ppm, tergolong sebagai antioksidan kuat sedangkan pada aktivitas antibakteri menunjukkan terbentuknya zona hambat pada kedua bakteri uji Staphylococcus aureus dan Escherichia coli masing-masing sebesar 12,4 mm dan $12,0 \mathrm{~mm}$.

\section{DAFTAR PUSTAKA}

[1] Athukorala, Y., Lee, K.W., Song, C.B., Ahn, C.B., Shin, T.S., Cha, Y.J., Shahidi, F., Jeon, Y.J., 2003. Potential Antioxidant Activity of Marine Red Alga Grateloupia Filicina Extracts. J. Food Lipids 10, 251-265.

[2] Heo, S.J., Jeon, Y.J., Lee, J., Kim, H.T., Lee, K.W., 2003. Antioxidant Effect of Enzymatic Hydrolyzate From a Kelp, Ecklonia cava. Algae 18, 341-347.

[3] Siriwardhana, N., Lee, K.W., Kim, S.H., Ha, J.W., Park, G.T., Jeon, Y.J., 2004. Lipid peroxidation inhibitory effects of Hizikia Fusiformis Methanolic Extract on Fish Oil and Linoleic Acid. Food Sci. Tech. Int. 10(2), 65-72.
[4] Khan M.A., Rahman, M.M. Sardar, M.N. Arman, M.S.I. Islam, M.B. Khandakar, M.J.A. Rashid, M. Sadik G., Alam A.H.M.K., 2016, Comparative Investigation of The Free Radical Scavenging Potential and Anticancer Property of Diospyros blancoi (Ebenaceae), Asian Pac. J. Trop. Biomed. 6 : 410-417.

[5] Dimitrijevic M. Jovanovic, V.S Cvetkovic,. J. MihajilovKrstev, T. Stojanovic, G. Mitic, V. 2015, Screening of Antioxidant, Antimicrobial and Antiradical Activities of Twelve Selected Serbian Wild Mushrooms, Anal. Methods. 7: 4181-4191.

[6] Das,S.C. Hamid, K. Bulbul, I.J. Sultana, S., 2010, In Vitro Antioxidant Activity of Different Parts of The Plant Diospyros Discolor Assessment of Free Radical Scavenging Activity by, Res. J. Agric. Biol. Sci. 6: 472475.

[7] Jang, H.W. Moon, J.K. Shibamoto T., 2015, Analysis and Antioxidant Activity of Extracts From Broccoli (Brassica oleracea L.) sprouts, J. Agric. Food Chem. 63 (2015), pp. 1169-1174.

[8] Khoddami, A. Wilkes, M.A. Roberts, T.H.. 2013, Techniques For Analysis of Plant Phenolic compounds, Molecules. 18 (2013) pp. 2328-2375.

[9] Kasote, D.M. Katyare, S.S. Hegde, M. V. Bae, H. , 2015, Significance of Antioxidant Potential of Plants and Its Relevance to Therapeutic Applications, Int. J. Biol. Sci. 11 : 982-991.

[10] Barbosa, -M., Valentão, -P., Andrade, P, -B., 2014. Bioactive Compounds From Macroalgae in The New Millennium: Implications For Neurodegenerative Diseases. Marine Drugs. 12, 4934-4972.

[11] Barot, -M., Kumar J, I, -N., Kumar, R, -N., 2016. Bioactive Compounds and Antifungal Activity of Three Different Seaweed Species Ulva lactuca, Sargassum tenerrimum and Laurencia obtusa collected from Okha Coast, Western India. Journal of Coastal Life Medicine. 4, pp. 284-289.

[12] Munne-bosch, S., 2012. Phenolic acids: Composition, Applications and Health Benefits. Nova Science Publishers, Inc., USA.

[13] Farvin, K. S., \& Jacobsen, C. (2013). Phenolic Compounds and Antioxidant Activities of Selected Species of Seaweeds from Danish Coast. Food Chem., 138(2-3), 1670-1681.

[14] Sidauruk SW, Sari NI, Diharmi A, Arif I. 2021. Aktivitas Antibakteri Ekstrak Sargassum plagyophyllum Terhadap Bakteri Listeria monocytogenes dan Pseudomonas aeruginosa. Jurnal Pengolahan Hasil Perikanan Indonesia. 24(1): 27-37.

[15] Sofiana M.S.J, Ikha Safitri, Shifa Helena, Warsidah, 2021, Phytochemical Screening, Total Penolic Content and Antioksidant Activity of Tropical Brown Macroalgae (Padina pavonica Hauck) from Kabung 
Island, West Kalimantan, Indonesian Journal of Fisheries Science and Technology, vol 17 No 1.

[16] Sofiana M.S.J, Aritonang AB, Safitri I, Helena S, Syarif Irwan Nurdiansyah, Risko, Dzul Fadly, Warsidah, 2020, Proximate, Phytochemicals, Total Phenolic Content and Antioxidant Activity of Ethanolic Extract of Eucheuma spinosum Seaweed, Sys Rev Phar, vol 11 No 8.

[17] Warsidah, Fadly, D., Bohari, 2020. Antibacterial and Anti-inflammatory Activities of Ethanol Extract Obtained from The Hooks of Uncaria tomentosa (Wild. Ex Schult) DC Originated Kalimantan, Indonesia. Syst. Rev. Pharm. 11, 65-70.

[18] Herrero, M., Cifuentes, A. and Ibañez, E., 2006. Suband Supercritical Fluid Extraction of Functional Ingredients from Different Natural Sources: Plants, Food-by-products, Algae and Microalgae: A review. Food chemistry, 98(1), pp. 136-148.

[19] Suleria, H.A.R., Osborne, S., Masci, P. and Gobe, G., 2015. Marine-based Nutraceuticals: An Innovative Trend in The Food and Supplement Industries. Marine drugs, 13(10), pp. 6336-6351.

[20] Tierney, M.S., Croft, A.K. dan Hayes, M. 2010. A Review of Antihypertensive and Antioxidant Activities in Macroalgae. Botanica Marina 53: 387-408.

[21] McDonald, S., Prenzler, P.D., Antolovich, M. and Robards, K. 2001. Phenolic Content and Antioxidant Activity of Olive Extracts. Food Chemistry 73: 73-84.

[22] Prior, R.L., Wu, X. \& Schaich, K. 2005. Standardized Methods for The Determination of Antioxidant Capacity and Phenolics in Foods and Dietary Supplements. Journal of Agricultural and Food Chemistry. 53(10), 4290-4302.

[23] Djapiala, F.Y., Lita, Montolalu, A.D.Y. dan Mentang, F. 2011. Kandungan Total Fenol Dalam Rumput Laut Caulerpa racemosa Yang Berpotensi Sebagai Sntioksidan. Jurnal Media Teknologi Hasil Perikanan 1: 5-9

[24] Prakash, A., Rigelhof, F., dan Miller, E., 2001, Antioxidant Activity, Medalliaoan Laboratories, Vol 19 (2): $1-4$

[25] Kuncahyo, I., dan Sunardi, 2007. Uji Aktivitas Ekstrak Belimbing Wuluh (Averhoa bilimbi L.) terhadap DPPH, SNT, 1-9.

[26] Blois, M.S. 1958. Antioxidant Determinations by The Use of A Stable Free Radical. Nature. 181:1199-1200

[27] Hwang, P., Chwen-Herg, W., Shu-Yun, G., Shih-Yung, C. dan Deng-Fwu, H. (2010). Antioxidant and Immunestimulating Activities of Hot-water Extract from Seaweed Sargassum hemiphyllum. Journal of Marine Science and Technology 18: 41-46.

[28] Boonchum, W., Peerapornpisal, Y., Kanjanapoth, D., Pekkoh, J., Pumas, C., Jamjai, U., Amornlerdpison, D.,
Noiraksar, T. dan Vacharapiyasophon, P. (2011). Antioxidant Activity of Some Seaweed from The Gulf of Thailand. International Journal of Agriculture and Biology 13: 95-99.

[29] Yangthong, M., Hutadilok-Towatana, M. dan Phromkunthong, W. 2009. Antioxidant Activities of Four Edible Seaweeds from The Southern Coast of Thailand. Plant Foods Human Nutrition 64: 218-223

[30] Cahyaningrum K, Husni A, Budhiyanti SA. 2016. Aktivitas Antioksidan Ekstrak Rumput Laut Coklat (Sargassum polycystum), Agritech journal, vol. 36 No 2.

[31] Shibata, T., Kawaguchi, S., Hama, Y., Inagaki, M., Yamaguchi, K. dan Nakamura, T. 2004. Local and Chemical Distribution of Phlorotannins in Brown Algae. Journal of Applied Phycology 16: 291-296

[32] Davis, W.W., dan T. R. Stout. 1971. Disc Plate Method of Microbiological Antibiotic Assay. Applied Microbiology. 22: 659 -665.

[33] Suryati, N., Bahar, E., Ilmiawati. 2017. Uji Efektivitas Antibakteri Ekstrak Aloe vera Terhadap Pertumbuhan Escherichia coli Secara In Vitro. Jurnal Kesehatan Andalas, 6(3): 518-522.

[34] Chairunisa, I., Indradi, R.B. 2020. Review Artikel: Aktivitas Antibakteri dan Kandungan Fitokimia Ekstrak Etanol Alga Merah (Eucheuma cottonii). Farmaka. 17(1): 105-110.

[35] Iskandar, Y, Rusmiati, D, Rusma, RD. 2010. Uji Efektivitas Antibakteri Ekstrak Etanol Rumput Laut Terhadap Bakteri Escherichia coli dan Bacillus cereus (skripsi). Bandung: Fakultas MIPA Universitas Padjajaran.

[36 ]Iriano A. 2008. Efektivitas Antibakteri Infusum Aloe vera Terhadap Porphyromonas gingivalis In Vitro (skripsi). Jakarta: Fakultas Kedokteran Gigi Universitas Indonesia; 2008. 